\title{
65 YEARS OF THE DOUBLE HELIX Exploiting insights on the RET receptor for personalized cancer medicine
}

\author{
Lois M Mulligan'1,2 \\ 1Division of Cancer Biology and Genetics, Cancer Research Institute, Queen's University, Kingston, Ontario, Canada \\ 2Department of Pathology and Molecular Medicine, Queen's University, Kingston, Ontario, Canada \\ Correspondence should be addressed to L M Mulligan: mulligal@queensu.ca
}

This paper is part of a thematic review section celebrating 65 Years of the Double Helix. The guest editors for this section were Charis Eng, William Foulkes and Jérôme Bertherat.

\begin{abstract}
The focus of precision cancer medicine is the use of patient genetic signatures to predict disease occurrence and course and tailor approaches to individualized treatment to improve patient outcomes. The rearranged during transfection (RET) receptor tyrosine kinase represents a paradigm for the power of personalized cancer management to change cancer impact and improve quality of life. Oncogenic activation of RET occurs through several mechanisms including activating mutations and increased or aberrant expression. Activating RET mutations found in the inherited cancer syndrome multiple endocrine neoplasia 2 permit early diagnosis, predict disease course and guide disease management to optimize patient survival. Rearrangements of RET found in thyroid and lung tumors provide insights on potential disease aggressiveness and offer opportunities for RET-targeted therapy. Aberrant RET expression in a subset of cases is associated with tumor dissemination, resistance to therapies and/or poorer prognosis in multiple cancers. The potential of RET targeting through repurposing of small-molecule multikinase inhibitors, selective RET inhibitors or other novel approaches provides exciting opportunities to individualize therapies across multiple pathologies where RET oncogenicity contributes to cancer outcomes.
\end{abstract} Key Words

As our appreciation of the genetic complexities underlying human pathologies increases, the imperative to precisely identify disease cause so that appropriate therapies can be applied has become the gold standard for patient care. Understanding the molecular effects of disease mutations, the mechanisms by which they cause cellular dysfunctions and the implications of these at the organismal level underlie the great strength of precision medicine to effectively target the patient's needs and improve outcomes. The rearranged during transfection
(RET) proto-oncogene represents a paradigm for the power of molecular medicine to drive changes in diagnosis and patient management that alter disease outcomes and patient quality of life. Originally identified as an oncogenic driver in thyroid cancer, RET is now recognized to have roles in familial and sporadic tumors of diverse types, where it has implications for diagnosis, prognosis and disease management. RET mutations, increased expression and functional polymorphic variants all have an impact on its oncogenic functions. As such, RET is a 
novel therapeutic target with increasing importance for personalized cancer medicine.

\section{The RET receptor}

RET is a receptor tyrosine kinase essential for normal development and maturation of diverse tissues (Schuchardt et al. 1994, Mulligan 2014). RET is required for the development of the kidney and for proliferation, differentiation and survival of central and peripheral nerve lineages, particularly those of the enteric nerve plexus, and other neuroendocrine cells, notably of the thyroid, adrenal and pituitary glands (Arighi et al. 2005, Paratcha \& Ledda 2008, Mulligan 2014, Lasrado et al. 2017). RET activity promotes the maturation of spermatogonia and the survival and expansion of hematopoietic stem cells, indicating its broad range of functions in developing and maturing tissues (Schuchardt et al. 1994, Meng et al. 2000, Fonseca-Pereira et al. 2014).

The mature RET receptor spans the plasma membrane, with a large extracellular domain containing cadherin-like repeats and a cysteine-rich region important for protein structure and ligand interactions (Wang 2013) (Fig. 1). The RET intracellular tyrosine kinase domain is required for autophosphorylation and phosphorylation of substrates that promote RET downstream signals through multiple pathways (Ibanez 2013, Mulligan 2014). Finally, RET has two functionally distinct protein isoforms that differ in C-terminal tail sequences due to alternative gene splicing and have differential contributions to both RET-mediated normal development and oncogenicity (de Graaff et al. 2001, Lian et al. 2017).

Under normal conditions, RET is activated by binding of a group of soluble glial cell line-derived neurotrophic factor (GDNF) ligands and a cell surface glycosylphosphatidylinositol-linked GDNF family receptor $\alpha$ (GFR $\alpha$ ) (Mulligan 2014, Ibanez \& Andressoo 2017) (Fig. 1). Binding of this ligand-coreceptor complex recruits RET into membrane domains called lipid rafts that act as hubs for RET-mediated activation of downstream signals (Mulligan 2014, Tsui et al. 2015). However, RET can also contribute to oncogenesis, either as a result of mutations that constitutively activate the RET kinase or by increased or aberrant activity of the WT receptor. Several types of RET mutations have been recognized that contribute to RET oncogenicity, and each of these is associated with specific tumor types and disease patterns (Mulligan 2014). The activating point mutations that cause multiple endocrine neoplasia type 2 (MEN2) and RET rearrangements found in thyroid and lung cancers are to date the best characterized of these mutations and have been the primary focus of RET precision medicine strategies.

\section{Multiple endocrine neoplasia 2}

MEN2 is an autosomal dominantly inherited cancer syndrome characterized by the occurrence of early-onset medullary thyroid carcinoma (MTC). The disease is further classified as two subtypes MEN2A and MEN2B, based on disease severity and associated phenotypes (Wells et al. 2015, Wells 2018). The more common subtype, MEN2A, representing $>95 \%$ of cases, may also be associated with the adrenal tumor pheochromocytoma (PCC) and parathyroid hyperplasia (HPT). A previously separate disease subtype, familial MTC, is now considered part of the MEN2A spectrum. In rare cases, MEN2A patients may have other noncancerous phenotypes, such as cutaneous lichen amyloidosis (itchy hyperpigmented epidermal plaques) or increased incidence of the congenital gut abnormality Hirschsprung disease (Wells et al. 2015). The clinically more severe MEN2B subtype has earlier disease onset and is also characterized by MTC and PCC but in addition, with developmental anomalies of several systems, including Marfanoid habitus, ganglioneuromas of the mouth and intestines and delayed puberty (Castinetti et al. 2018). Over $90 \%$ of MEN2B presents as de novo cases, making timely diagnosis challenging (Brauckhoff et al. 2014, Castinetti et al. 2018).

MEN2 is caused by gain-of-function mutations of the RET receptor (Mulligan 2014). These are primarily point mutations, creating single amino acid substitutions that lead to constitutive RET kinase activity. MEN2 mutations are found in $R E T$ exons 5-16, but the majority of the $>60$ pathogenic variants detected to date cluster at fewer than 15 residues (Margraf et al. 2009). There are strong associations of disease phenotype and RET mutation genotype. Risks of developing PCC and HPT are mutation dependent, which has been extremely valuable in guiding recommendations for disease management (Mulligan et al. 1994, Eng et al. 1996, Wells et al. 2015). Over 95\% of MEN2A cases arise from substitutions of cysteine residues in the RET extracellular domain (C609, C611, C618, C620, C634) that allow receptor dimerization and constitutive activity in the absence of ligand (Mulligan et al. 1994, Eng et al. 1996) (Figs 1 and 2). Other less common MEN2A mutations in the RET extracellular domain (e.g. G533C) or intracellular domain (residues E768, L790, V804, S891) are generally associated with more indolent disease or later disease onset or with MTC as the only disease feature (Machens \& Dralle 2008, Mulligan 2014, Wells 2018). 
A

RET

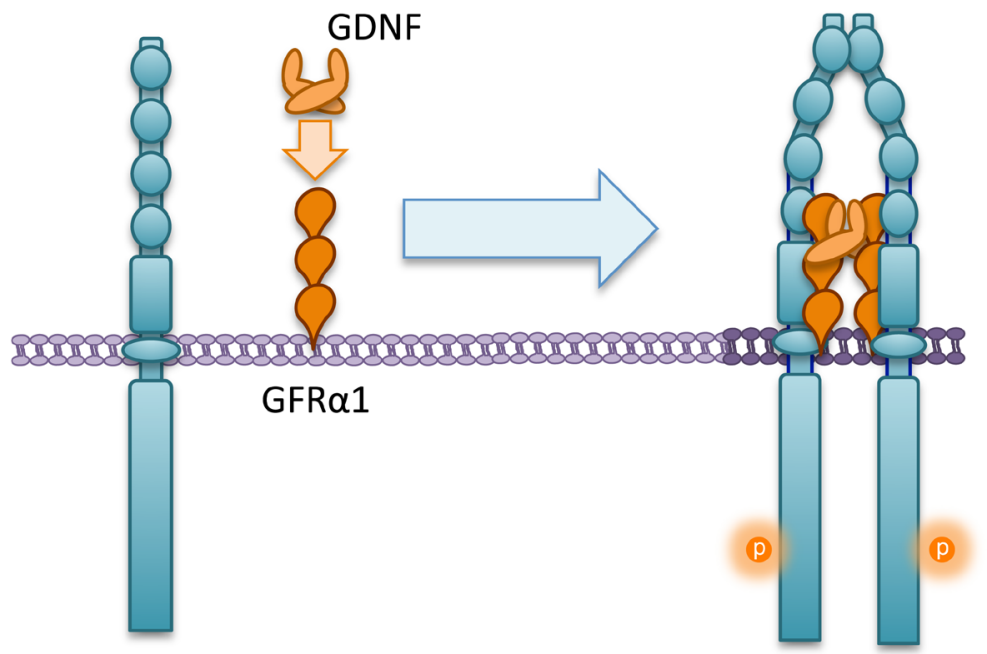

B

\section{RET}

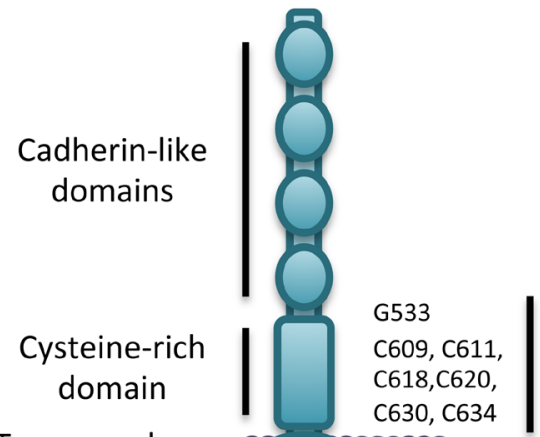

MEN2A

Transmembrane

C630, C634

domain

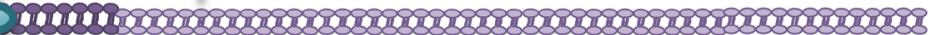
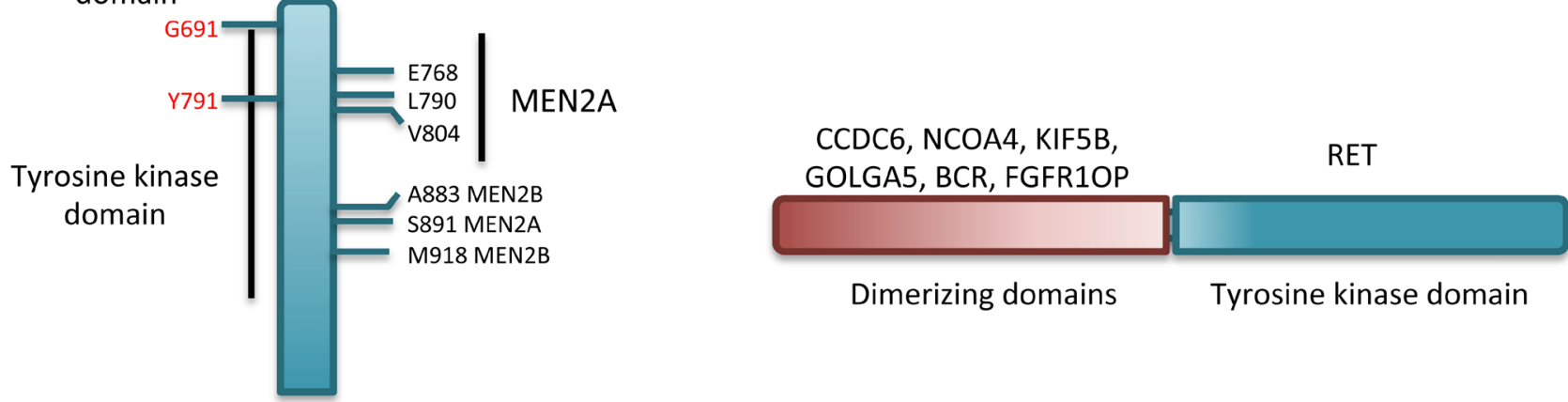

Figure 1

The RET receptor tyrosine kinase and its oncogenic mutations. (A) Activation of WT RET occurs by binding of a GDNF ligand to GFR $\alpha$. This complex binds and promotes RET activity. (B) Schematic diagram showing locations of the common RET mutations identified in MEN2 patients (left) and RET rearrangements found in multiple cancers (right). The locations of RET mutations that give rise to MEN2 and the associated disease phenotypes are indicated. Two sequence variants suggested to act as modifiers, either affecting severity of other RET mutations or as risk-associated alleles in other cancers, are indicted in red. RET fusion proteins are located in the cytosol. RET kinase domain and partner genes that provide dimerization domains that permit constitutive activation, are indicated. GDNF, glial cell line-derived neurotrophic factor; GFR $\alpha$, GDNF receptor $\alpha$; MEN2, multiple endocrine neoplasia type 2; RET, rearranged during transfection. 


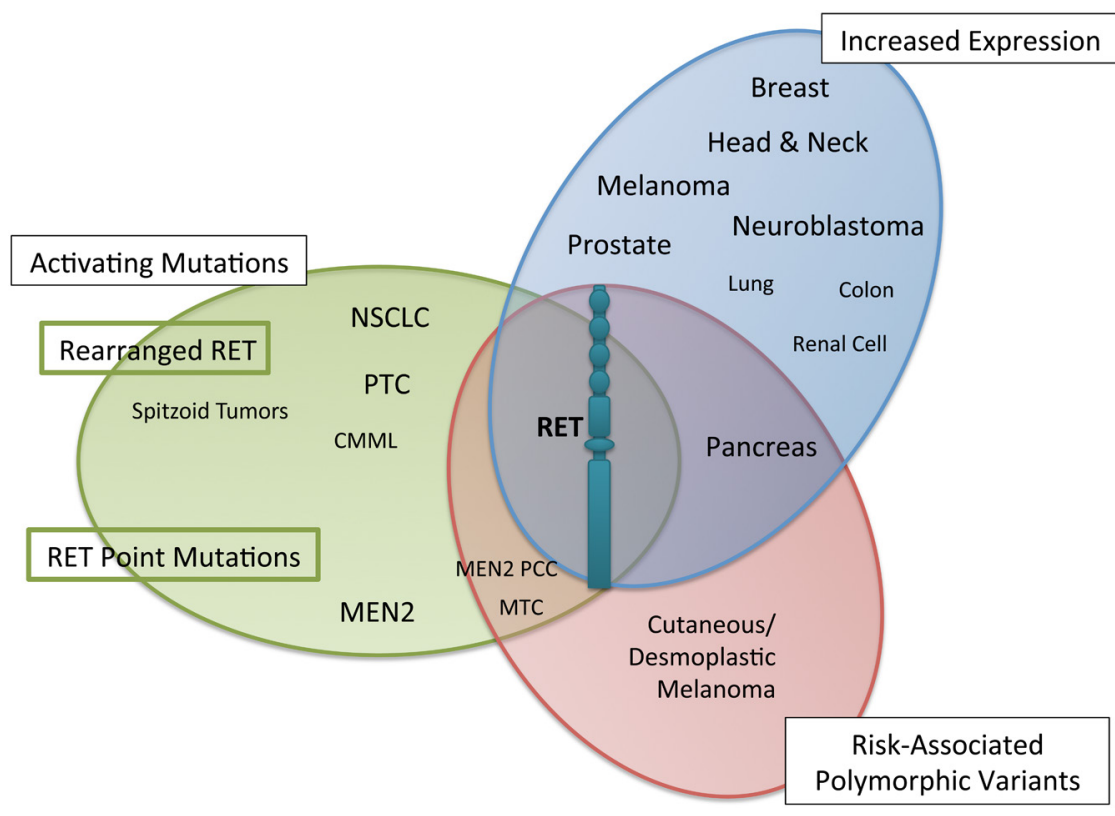

Figure 2

Mechanisms of RET-associated oncogenicity in human cancers. Contributions of RET mutations (green); risk-associated variants (red) and increased expression (blue) are summarized. Text size is indicative of the relative level of support for RET association. CMML, chronic myelomonocytic leukemia; NSCLC, non-small-cell lung carcinoma; PTC, papillary thyroid carcinoma; RET, rearranged during transfection.
MEN2B is uniquely associated with a substitution of a methionine at codon 918 for threonine, within the RET catalytic domain, close to the activation loop of the kinase (Gujral et al. 2006, Knowles et al. 2006). These mutants have altered phosphorylation kinetics, and tenfold increased ATP-binding and kinase activity, allowing robust activation of downstream signals (Gujral et al. 2006, Plaza-Menacho 2018). In some cases, an alanineto-phenylalanine change at codon 883 in the RET kinase domain, also proximal to the activation loop, has been linked to MEN2B, but may be associated with a less aggressive form of the disease (Jasim et al. 2011, Mathiesen et al. 2017). In rare instances, an MEN2B variant has been reported associated with dual mutations in cis lying close to the ATP-binding pocket of the RET kinase (e.g. V804M, Y806C). The two variants act synergistically to enhance RET activity; however, the phenotypes of these patients are not fully consistent with MEN2B but are generally more indolent than M918T mutants (Cranston et al. 2006, Nakao et al. 2013). Interestingly, MEN2B-type RET mutations occur somatically in approximately $65 \%$ of sporadic MTCs where they are associated with more aggressive disease (Elisei et al. 2008, Moura et al. 2009).

Prior to identification of RET mutations in 1993 (Donis-Keller et al. 1993, Mulligan et al. 1993), MEN2 diagnosis was based on family history and the inheritance of linked markers (Calmettes et al. 1992). As MTC responds poorly to standard chemotherapy and radiotherapy, the primary treatment is surgical intervention. Repeated biochemical screening in at-risk individuals for the MTC precursor lesion C-cell hyperplasia or early-stage disease was used to identify those family members carrying the MEN2 mutation and to plan the timing of thyroidectomy. Unfortunately, these assays had relatively frequent false positives leading to unnecessary surgeries (Marsh et al. 1996). Further, even with regular screening, it was not always possible to detect nascent MTC before it spread, reducing long-term survival and quality of life in these patients. The identification of the underlying genetic cause of MEN2 has profoundly changed disease management (Wells et al. 1994, 2015, Learoyd et al. 1997, Dralle et al. 1998, Machens \& Dralle 2018, Wells 2018). Genetic testing for MEN2 RET mutations as early as possible is now standard of care for all at-risk individuals (Wells et al. 2015). Confirmation of RET mutation status eliminates the need for repeated biochemical screening for those who have not inherited the disease allele and can focus resources on those who will develop MEN2. Presymptomatic genetic testing allows for prophylactic or very early interventions in these individuals, before disease has a chance to spread outside the thyroid (Wells et al. 2015, Machens \& Dralle 2018, Wells 2018). Testing is also valuable in apparently sporadic MTC cases as $7-15 \%$ of these have germline RET mutations and represent de novo MEN2 cases (Eng et al. 1995, Romei et al. 2011).

Importantly, the association of specific disease phenotypes with RET mutation genotype in MEN2 has offered the opportunity to tailor management recommendations optimally based on the identified disease mutation. For individuals with the highest risk MEN2B RET mutation (M918T), which is associated with earliest onset and most aggressive phenotypes, 
prophylactic thyroidectomy is recommended in the first year of life (Wells et al. 2015), since MTC micrometastases have been recognized as early as 3 months of age (Sanso et al. 2002, Zenaty et al. 2009). In individuals with other mutations considered high risk, including the most common MEN2A mutation, C634R and the MEN2B A883F mutations, surgery should be performed before age 5 years. The remaining, so-called 'moderate risk' RET mutations, may be associated with later or more variable age of onset, and an individualized combination of biochemical monitoring and thyroidectomy based on age of onset in family members is recommended (Wells et al. 2015, Voss et al. 2017). Importantly, despite these differences, recent analyses have found very little difference in overall survival and distant metastasis for patients with high- or moderate-risk RET mutations when age at diagnosis is taken into account highlighting the need for the earliest possible genetic testing (Voss et al. 2017). Monitoring for PCC and HPT can also be prioritized based on RET mutation, as PCC is much more common in patients with C634 ( $90 \%$ by age 80 years) or M918 ( 100\%) mutations, while parathyroid involvement occurs primarily with C634R mutations (Mulligan et al. 1994, Eng et al. 1996, Imai et al. 2013).

RET mutation-guided management has significantly improved disease outcomes and quality of life for MEN2A patients (Grey \& Winter 2018, Machens \& Dralle 2018, Machens et al. 2018). Early genetic screening in these patients provides the earliest possible opportunity for prophylactic thyroidectomy or surgical intervention before MTC has spread outside the thyroid, thereby reducing the need for extensive lymph node dissections, reducing morbidity from surgical complications (Machens \& Dralle 2018, Machens et al. 2018). Effective cure for MEN2A patients detected by presymptomatic mutation screening approaches $100 \%$, compared to 10 -year survival rates as low as $40 \%$ for MTC patients with extensive metastasis at diagnosis (Lodish \& Stratakis 2008). In contrast, MEN2B predominantly results from de novo RET mutations and therefore genetic screening is not generally guided by family history. Further, MEN2B is clinically more aggressive, with earlier metastasis, narrowing the window where early thyroidectomy will provide effective cure (Brauckhoff et al. 2014, Castinetti et al. 2018). Thus, early recognition of nonendocrine signs of MEN2B, detailed earlier (Brauckhoff et al. 2014, Castinetti et al. 2018), by pediatricians, dentists and other health care providers is critical to minimizing delays in diagnosis and improving outcomes. Despite advances, surgical cure for MEN2B-MTC operated after age 4 years is rare
(Brauckhoff et al. 2014, Machens \& Dralle 2018). Since MEN2B de novo cases are often diagnosed much later than this, prophylactic thyroidectomy is not the norm and morbidity for this disease subtype is much higher. Thus, MEN2B patients in particular benefit from more recent advances in RET-targeted therapies, discussed below (Fox et al. 2013, Schlumberger et al. 2017). Nonetheless, RET mutation detection as early as possible in these cases also permits an appropriate regimen of follow-up testing and screening for PCC.

\section{RET polymorphic variants and cancer risk}

In addition to MEN2-RET pathogenic mutations, there are several polymorphic sequence variants that act as modifiers of RET mutation genotype. Combinations of polymorphic $R E T$ coding or intronic sequence variants have been suggested to increase MTC or MEN2A-PCC risk (McWhinney et al. 2003, Ceolin et al. 2012, Siqueira et al . 2014, Lebeault et al. 2017). The Y791F non-synonymous variant lies within the RET kinase domain and was originally thought to be a pathogenic mutation, while the G691S variant lies in the juxtamembrane region of RET (Fig. 1). In families, co-occurrence of either of these variants with other MEN2A mutations enhances disease severity and promotes earlier onset of some, or all, disease phenotypes (Robledo et al. 2003, Toledo et al. 2010, 2015, Lantieri et al. 2013, Colombo et al. 2015), making assessment of these variants a valuable contribution to improve disease management. Interestingly, the G691S variant is also over represented in patients with sporadic MTC, pancreatic ductal adenocarcinoma and cutaneous or desmoplastic melanoma (Fig. 2), and may be correlated with increased tumor growth or invasion (Elisei et al. 2004, Sawai et al. 2005, Narita et al. 2009) suggesting this variant may act as a modifier or low penetrance risk allele in these cancers also.

\section{RET rearrangements}

A distinct group of oncogenic mutations are the somatically occurring rearrangements of the RET gene (Fig. 2). As a result of chromosomal rearrangement or inversion, gene sequences encoding the intracellular kinase domain of RET become juxtaposed to $5^{\prime}$ sequences from a partner gene containing protein dimerization domains (Fig. 1). The resultant chimeric proteins are constitutively dimerized and localized in the cytosol, where they escape regulation by the mechanisms controlling the WT RET protein at the cell membrane and enhance signaling, 
particularly through MAP kinase pathways (Richardson et al. 2009, Xing 2013). RET rearrangements are identified in $20-40 \%$ of papillary thyroid carcinomas (PTCs) and incidence varies geographically (Hamatani et al. 2008, Leeman-Neill et al. 2013, Liang et al. 2018). Although close to 20 different partner genes have been recognized to date, the most frequent rearrangements involve the genes for coiled-coil domain containing 6 (CCDC6) termed RET-PTC1 and the nuclear receptor co-activator 4 (NCOA4; RET-PTC3) (Romei et al. 2016). RET rearrangements, and particularly RET-PTC3, are associated with more aggressive PTC histology (Romei et al. 2016) and promote tumor cell migration and invasion in vitro (Lian et al. 2017).

Similar forms of RET rearrangements are identified in $\sim 1-2 \%$ non-small-cell lung carcinomas (NSCLCs), where they are more prevalent in younger patients and represent $6-19 \%$ of tumors in never smokers without any other genetic cause (Ferrara et al. 2018). At least 12 different RET fusions have been recognized, but interestingly, these chimeras involve a different distribution of RET partner genes than in PTC, with rearrangements involving kinesin family 5B (KIF5B) and CCDC6 being the most prevalent events (Gautschi et al. 2017, Ferrara et al. 2018). In particular, the KIF5B-RET rearrangement results in a 2- to 30-fold increase in expression of the RET kinase, suggesting that the fusion protein is responsible for transformation in these tumors (Kohno et al. 2012) and highlighting it as an actionable therapeutic target (Gautschi et al. 2017).

As deep sequencing methods are applied more broadly to human cancers, RET fusions are beginning to be discovered as rare events in other cancers as well. RET rearrangements with several partners (GOLGA5, KIF5B) are found in $~ 3 \%$ of Spitzoid tumors (Wiesner et al. 2014). RET fusion with the breakpoint cluster region protein (BCR) or fibroblast growth factor receptor 1 oncogene partner (FGFR1OP) genes have been identified infrequently in chronic myelomonocytic leukemia (Ballerini et al. 2012). Rare examples of RET fusions have also been found in breast, colon, ovarian, salivary gland and inflammatory myofibroblastic tumors (Stransky et al. 2014, Antonescu et al. 2015, Kato et al. 2017), suggesting potential value of customized strategies for targeting of patients with RET anomalies.

\section{RET expression in other tumors}

In addition to oncogenic mutations, altered RET expression is also detected in diverse tumor types where it may provide an actionable therapeutic target. Increased expression and activation of RET receptors is detected in approximately $30-70 \%$ of breast cancers, and expression is somewhat more common in estrogen receptor-positive tumors (Morandi et al. 2011, 2013, Gattelli et al. 2013). RET has been linked to larger tumors, higher stage and decreased metastasis-free and overall survival in these patients (Plaza-Menacho et al. 2010, Wang et al. 2012, Morandi et al. 2013). Increased RET levels are also associated with resistance to multiple endocrine therapy modalities (tamoxifen, aromatase inhibitors, fulvestrant), which are key tools in targeting hormone receptorpositive breast cancers (Plaza-Menacho et al. 2010, Gattelli et al. 2013, Morandi et al. 2013). Preclinical models have suggested benefit in targeting RET in breast cancer where it might act as an adjuvant to block tumor growth and increase response to endocrine therapies (Nguyen et al. 2015, Andreucci et al. 2016, Hatem et al. 2016, Gattelli et al. 2018).

Elevated RET expression is detected in 50-65\% of pancreatic ductal adenocarcinomas, particularly in higher grade tumors, where it promotes metastasis and perineural invasion, the spread of tumor cells along nerve fibers, which is associated with poor prognosis and tumor-related pain (Zeng et al. 2008, Gil et al. 2010, Amit et al. 2017). In prostate adenocarcinomas, increased RET expression may increase proliferation and is also linked to perineural invasion (Dawson et al. 1998, Ban et al. 2017). Some level of RET expression is detected in a number of other cancers including melanoma, head and neck tumors, neuroblastoma, and lung, colon and renal cell carcinomas (Fig. 2) (Narita et al. 2009, Flavin et al. 2012, Luo et al. 2013, Kosari et al. 2014, Lin et al. 2016). The oncogenic importance of RET in tumor growth and spread in these diseases and its value as a therapeutic target is yet to be fully characterized.

\section{RET-targeted therapies}

The holy grail of precision medicine is to establish the patient-specific disease mechanisms that allow us to 'personalize' cancer therapy to improve individual care outcomes. As summarized here, RET is an important driver of both familial and sporadic cancers (Fig. 2), and RET-targeted therapies have potential applications in diverse cancers. There are currently no RET-specific agents approved for clinical use; however, multikinase inhibitors originally developed to target conserved regions of other kinases have also shown efficacy against RET (Redaelli et al. 2018). The ATP-competitive multikinase inhibitors vandetanib and cabozantinib effectively block activity and 
signaling of both full-length and fusion RET proteins and have been approved for use in patients with progressive unresectable MTC or treatment-resistant PTC (Wells et al. 2012, Elisei et al. 2013, Redaelli et al. 2018). These drugs have significantly improved progression-free survival (PFS), leading to stable disease or increased duration of response in patients with advanced or metastatic MTC (Wells et al. 2012, Karras et al. 2013, Schlumberger et al. 2015, Viola et al. 2016). Importantly, treatment provides significant improvements in PFS and overall survival for MTC patients with RET M918T mutations, which respond very poorly to other chemotherapies, although some initial studies with cabozantinib suggest that benefits for other RET mutations may be more modest (Fox et al. 2013, Schlumberger et al. 2015, 2017). Notably, some specific MEN2 RET mutations that affect the 'gate keeper' residue (V804) adjacent to the RET ATP-binding pocket, block binding of inhibitors to RET and confer resistance to these agents (Carlomagno et al. 2004), making RET mutation genotype an important determinant of treatment success. Recent clinical trials have also shown vandetanib and cabozantinib increase PFS for lung adenocarcinoma expressing $R E T$ fusion genes, and this is more pronounced for KIF5B-RET than CCDC6-RET fusions (Drilon et al. 2013, Yoh et al. 2017), potentially due to its greater activity. In breast preclinical models, targeting RET with multikinase inhibitors in combination with anti-estrogens has shown some promise for restoring sensitivity to endocrine therapies and blocking tumor growth and/or dissemination (Gattelli et al. 2013, Andreucci et al. 2016).

A number of additional multikinase inhibitors are being evaluated in clinical trials in RET-expressing cancers and have shown promise in single cases or small series (recently reviewed in Drilon et al. 2018, Redaelli et al. 2018). These are primarily ATP-competitive inhibitors that vary in their kinase targets and RET inhibitory profiles, and in their ability to inhibit RET gatekeeper mutants. However, all these multikinase inhibitors, including vandetanib and cabozantinib, are associated with significant toxicities, likely due to systemic effects of the 'off target' inhibition of other kinases such as EGFR or VEGFR family kinases (Wells et al. 2012, Schlumberger et al. 2015, 2017). Further, the recent report of an acquired V804M mutation in a metastatic MTC previously treated with multiple tyrosine kinase inhibitors (Subbiah et al. $2018 b$ ), suggests the potential for development of drug resistance in response to extended treatment with these inhibitors, as has been seen for other targeted therapies.

The next generation of novel RET-selective agents show potent inhibition of RET activity in vitro and in preclinical models and are broadly effective against RET full-length and fusion proteins as well as the RET gatekeeper mutants (e.g. Newton et al. 2016, Ardini et al. 2018, Fujita et al. 2018, Subbiah et al. 2018a,b). Two of these inhibitors, BLU-667 and LOXO-292, have $>100$-fold greater selectivity for RET compared to other kinases in cell-based and preclinical animal models (Drilon et al. 2018, Subbiah et al. 2018a,b). Phase I trials for both of these agents are currently underway but early results are promising, showing low toxicity and significantly improved inhibition of the range of RET mutants (Subbiah et al. 2018a,b). Trials of additional RET-targeted agents are likely to follow soon. Interestingly, early data suggest that LOXO-292 crosses the blood-brain barrier and may be effective for management of brain metastases, particularly in NSCLC (Subbiah et al. 2018b).

Alternative strategies for targeting RET, such as antibody-drug conjugates, provide additional modalities that may complement existing ATP-competitive inhibitors and avoid the potential for acquired resistance (Nguyen et al. 2015). Combination therapies, using RET inhibitors in conjunction with agents to block downstream pathways, are also showing promising effects. The combination of RET and mTOR inhibitors induces synergistic growth inhibition in MTC cells and may enhance RET inhibitor delivery to the central nervous system, essential to target NSCLC brain metastasis (Gild et al. 2013, Subbiah et al. 2015).

\section{The future: from cause to cure}

The RET receptor is a 'poster child' for the potential of precision medicine strategies to change the ways we understand and manage cancer risks, but there are still many avenues to improve patient care. The identification of individual $R E T$ mutations allows accurate presymptomatic diagnosis and prediction of disease course in MEN2, which permits personalized disease management. Sensitive liquid biopsy approaches are being developed to identify RET mutations in circulating tumor cells or cell-free DNA, which will speed the recognition of primary or recurrent RET-driven cancers, identify candidates for RET-targeted therapies and provide accurate monitoring of response to therapy, disease recurrence or acquired drug resistance (Cote et al. 2017, Reckamp et al. 2018). Exciting developments of highly selective small-molecule RET inhibitors and combination therapies are changing the way we manage RET-associated cancers today, but new approaches to complement these are needed. Novel strategies using 
agents to block RET expression (e.g. ellipticine analogs (Kumarasamy \& Sun 2017)) or enhance RET degradation (e.g. heat shock protein inhibitors (Alfano et al. 2010)) are already being explored in preclinical models. Studies identifying direct modulators of RET expression (e.g. estrogen receptor $\alpha$, ATF4, TFAP2C), and RET-negative regulators (e.g. HSP90, CBL and NEDD4 ubiquitin ligases), suggest additional potential actionable processes to limit RET function that could be used in combination with RET inhibitors to improve their therapeutic efficacy and limit the development of drug resistance (Alfano et al. 2010, Bagheri-Yarmand et al. 2017, Hyndman et al. 2017). Together, RET's oncogenic roles make it an important therapeutic target across many cancer types, and it is likely that this will only increase as we delve more broadly into diverse cancer genomes.

\section{Declaration of interest}

The author declares that there is no conflict of interest that could be perceived as prejudicing the impartiality of this review.

\section{Funding}

This work did not receive any specific grant from any funding agency in the public, commercial or not-for-profit sector.

\section{References}

Alfano L, Guida T, Provitera L, Vecchio G, Billaud M, Santoro M \& Carlomagno F 2010 RET is a heat shock protein 90 (HSP90) client protein and is knocked down upon HSP90 pharmacological block. Journal of Clinical Endocrinology and Metabolism 95 3552-3557. (https://doi.org/10.1210/jc.2009-2315)

Amit M, Na'ara S, Leider-Trejo L, Binenbaum Y, Kulish N, Fridman E, Shabtai-Orbach A, Wong RJ \& Gil Z 2017 Upregulation of RET induces perineurial invasion of pancreatic adenocarcinoma. Oncogene 36 3232-3239. (https://doi.org/10.1038/onc.2016.483)

Andreucci E, Francica P, Fearns A, Martin LA, Chiarugi P, Isacke CM \& Morandi A 2016 Targeting the receptor tyrosine kinase RET in combination with aromatase inhibitors in ER positive breast cancer xenografts. Oncotarget 7 80543-80553. (https://doi.org/10.18632/ oncotarget.11826)

Antonescu CR, Suurmeijer AJ, Zhang L, Sung YS, Jungbluth AA, Travis WD, Al-Ahmadie H, Fletcher CD \& Alaggio R 2015 Molecular characterization of inflammatory myofibroblastic tumors with frequent ALK and ROS1 gene fusions and rare novel RET rearrangement. American Journal of Surgical Pathology 39 957-967. (https://doi.org/10.1097/PAS.0000000000000404)

Ardini E, Banfi P, Avanzi N, Ciomi M, Polucci P, Cirla A, D'Anello M, Lombardi Borgia A, Cristiani C, Ballinari D, et al. 2018 NMS-E668, a highly potent orally available RET inhibitor with selectivity towards VEGFR2 and demonstrated antitumor efficacy in multiple RET-driven cancer models. In Proceedings of the 109th Annual Meeting of the American Association for Cancer Research 2018, abstract 4785. Chicago, IL, USA: AACR.

Arighi E, Borrello MG \& Sariola H 2005 RET tyrosine kinase signaling in development and cancer. Cytokine and Growth Factor Reviews 16 441-467. (https://doi.org/10.1016/j.cytogfr.2005.05.010)
Bagheri-Yarmand R, Williams MD, Grubbs EG \& Gagel RF 2017 ATF4 targets RET for degradation and is a candidate tumor suppressor gene in medullary thyroid cancer. Journal of Clinical Endocrinology and Metabolism 102 933-941. (https://doi.org/10.1074/jbc. M114.619833)

Ballerini P, Struski S, Cresson C, Prade N, Toujani S, Deswarte C, Dobbelstein S, Petit A, Lapillonne H, Gautier EF, et al. 2012 RET fusion genes are associated with chronic myelomonocytic leukemia and enhance monocytic differentiation. Leukemia 26 2384-2389. (https://doi.org/10.1038/leu.2012.109)

Ban K, Feng S, Shao L \& Ittmann M 2017 RET signaling in prostate cancer. Clinical Cancer Research 23 4885-4896. (https://doi. org/10.1158/1078-0432.CCR-17-0528)

Brauckhoff M, Machens A, Lorenz K, Bjoro T, Varhaug JE \& Dralle H 2014 Surgical curability of medullary thyroid cancer in multiple endocrine neoplasia 2B: a changing perspective. Annals of Surgery 259 800-806. (https://doi.org/10.1097/SLA.0b013e3182a6f43a)

Calmettes C, Ponder B, Fischer J \& Raue F 1992 Early diagnosis of the multiple endocrine neoplasia type 2 syndrome: consensus statement. European community concerted action: medullary thyroid carcinoma. European Journal of Clinical Investigation 22 755-760. (https://doi.org/10.1111/j.1365-2362.1992.tb01441.x)

Carlomagno F, Guida T, Anaganti S, Vecchio G, Fusco A, Ryan AJ, Billaud M \& Santoro M 2004 Disease associated mutations at valine 804 in the RET receptor tyrosine kinase confer resistance to selective kinase inhibitors. Oncogene 23 6056-6063. (https://doi.org/10.1038/ sj.onc.1207810)

Castinetti F, Moley J, Mulligan LM \& Waguespack SG 2018 A comprehensive review on MEN 2B. Endocrine-Related Cancer 25 T29-T39. (https://doi.org/10.1530/ERC-17-0209)

Ceolin L, Siqueira DR, Ferreira CV, Romitti M, Maia SC, Leiria L, Crispim D, Ashton-Prolla P \& Maia AL 2012 Additive effect of RET polymorphisms on sporadic medullary thyroid carcinoma susceptibility and tumor aggressiveness. European Journal of Endocrinology 166 847-854. (https://doi.org/10.1530/EJE-11-1060)

Colombo C, Minna E, Rizzetti MG, Romeo P, Lecis D, Persani L, Mondellini P, Pierotti MA, Greco A, Fugazzola L, et al. 2015 The modifier role of RET-G691S polymorphism in hereditary medullary thyroid carcinoma: functional characterization and expression/ penetrance studies. Orphanet Journal of Rare Diseases 10 25. (https:// doi.org/10.1186/s13023-015-0231-z)

Cote GJ, Evers C, Hu MI, Grubbs EG, Williams MD, Hai T, Duose DY, Houston MR, Bui JH, Mehrotra M, et al. 2017 Prognostic significance of circulating RET M918T mutated tumor DNA in patients with advanced medullary thyroid carcinoma. Journal of Clinical Endocrinology and Metabolism 102 3591-3599. (https://doi. org/10.1210/jc.2017-01039)

Cranston AN, Carniti C, Oakhill K, Radzio-Andzelm E, Stone EA, McCallion AS, Hodgson S, Clarke S, Mondellini P, Leyland J, et al. 2006 RET is constitutively activated by novel tandem mutations that alter the active site resulting in multiple endocrine neoplasia type 2B. Cancer Research 66 10179-10187. (https://doi.org/10.1158/00085472.CAN-06-0884)

Dawson DM, Lawrence EG, MacLennan GT, Amini SB, Kung HJ, Robinson D, Resnick MI, Kursh ED, Pretlow TP \& Pretlow TG 1998 Altered expression of RET proto-oncogene product in prostatic intraepithelial neoplasia and prostate cancer. Journal of the National Cancer Institute 90 519-523. (https://doi.org/10.1093/jnci/90.7.519)

de Graaff E, Srinivas S, Kilkenny C, D'Agati V, Mankoo BS, Costantini F \& Pachnis V 2001 Differential activities of the RET tyrosine kinase receptor isoforms during mammalian embryogenesis. Genes and Development 15 2433-2444. (https://doi. org/10.1101/gad.205001)

Donis-Keller H, Dou S, Chi D, Carlson KM, Toshima K, Lairmore TC, Howe JR, Moley JF, Goodfellow P \& Wells SA 1993 Mutations in the RET proto-oncogene are associated with MEN 2A and FMTC. Human Molecular Genetics 2 851-856. (https://doi.org/10.1093/hmg/2.7.851) 
Dralle H, Gimm O, Simon D, Frank-Raue K, Gortz G, Niederle B, Wahl RA, Koch B, Walgenbach S, Hampel R, et al. 1998 Prophylactic thyroidectomy in 75 children and adolescents with hereditary medullary thyroid carcinoma: German and Austrian experience. World Journal of Surgery 22 744-750. (https://doi.org/10.1007/ s002689900463)

Drilon A, Wang L, Hasanovic A, Suehara Y, Lipson D, Stephens P, Ross J, Miller V, Ginsberg M, Zakowski MF, et al. 2013 Response to cabozantinib in patients with RET fusion-positive lung adenocarcinomas. Cancer Discovery 3 630-635. (https://doi. org/10.1158/2159-8290.CD-13-0035)

Drilon A, Hu ZI, Lai GGY \& Tan DSW 2018 Targeting RET-driven cancers: lessons from evolving preclinical and clinical landscapes. Nature Reviews Clinical Oncology 15 151-167. (https://doi. org/10.1038/nrclinonc.2017.175)

Elisei R, Cosci B, Romei C, Bottici V, Sculli M, Lari R, Barale R, Pacini F \& Pinchera A 2004 RET exon 11 (G691S) polymorphism is significantly more frequent in sporadic medullary thyroid carcinoma than in the general population. Journal of Clinical Endocrinology and Metabolism 89 3579-3584. (https://doi.org/10.1210/jc.2003-031898)

Elisei R, Cosci B, Romei C, Bottici V, Renzini G, Molinaro E, Agate L, Vivaldi A, Faviana P, Basolo F, et al. 2008 Prognostic significance of somatic RET oncogene mutations in sporadic medullary thyroid cancer: a 10-year follow-up study. Journal of Clinical Endocrinology and Metabolism 93 682-687. (https://doi.org/10.1210/jc.2007-1714)

Elisei R, Schlumberger MJ, Muller SP, Schoffski P, Brose MS, Shah MH, Licitra L, Jarzab B, Medvedev V, Kreissl MC, et al. 2013 Cabozantinib in progressive medullary thyroid cancer. Journal of Clinical Oncology 31 3639-3646. (https://doi.org/10.1200/JCO.2012.48.4659)

Eng C, Mulligan LM, Smith DP, Healey CS, Frilling A, Raue F, Neumann HPH, Ponder MA \& Ponder BAJ 1995 Low frequency of germline mutations in the RET proto-oncogene in patients with apparently sporadic medullary thyroid carcinoma. Clinical Endocrinology 43 123-127. (https://doi.org/10.1111/j.1365-2265.1995. tb01903.x)

Eng C, Clayton D, Schuffenecker I, Lenoir G, Cote G, Gagel RF, Ploos van Amstel H-K, Lips CJM, Nishisho I, Takai S-I, et al. 1996 The relationship between specific RET proto-oncogene mutations and disease phenotype in multiple endocrine neoplasia type 2 : international RET mutation consortium. JAMA 276 1575-1579. (https://doi.org/10.1001/jama.1996.03540190047028)

Ferrara R, Auger N, Auclin E \& Besse B 2018 Clinical and translational implications of RET rearrangements in non-small cell lung cancer. Journal of Thoracic Oncology 13 27-45. (https://doi.org/10.1016/j. jtho.2017.10.021)

Flavin R, Finn SP, Choueiri TK, Ingoldsby $\mathrm{H}$, Ring M, Barrett $\mathrm{C}$, Rogers M, Smyth P, O'Regan E, Gaffney E, et al. 2012 RET protein expression in papillary renal cell carcinoma. Urologic Oncology 30 900-905. (https://doi.org/10.1016/j.urolonc.2010.08.025)

Fonseca-Pereira D, Arroz-Madeira S, Rodrigues-Campos M, Barbosa IA, Domingues RG, Bento T, Almeida AR, Ribeiro H, Potocnik AJ, Enomoto H, et al. 2014 The neurotrophic factor receptor RET drives haematopoietic stem cell survival and function. Nature 514 98-101. (https://doi.org/10.1038/nature13498)

Fox E, Widemann BC, Chuk MK, Marcus L, Aikin A, Whitcomb PO, Merino MJ, Lodish M, Dombi E, Steinberg SM, et al. 2013 Vandetanib in children and adolescents with multiple endocrine neoplasia type 2B associated medullary thyroid carcinoma. Clinical Cancer Research 19 4239-4248. (https://doi.org/10.1158/1078-0432. CCR-13-0071)

Fujita H, Miyazaki I, Kato M, Yamada Y, Ishida K, Haruma T, Nagasaki H, Ito K, Hashimoto A, Kodama Y, et al. 2018 TAS0286/HM05, a novel highly selective RET inhibitor, prominently inhibits various RET defective tumor growth. In Proceedings of the 109th Annual Meeting of the American Association for Cancer Research 2018, abstract 4784. Chicago, IL, USA: AACR.
Gattelli A, Nalvarte I, Boulay A, Roloff TC, Schreiber M, Carragher N, Macleod KK, Schlederer M, Lienhard S, Kenner L, et al. 2013 Ret inhibition decreases growth and metastatic potential of estrogen receptor positive breast cancer cells. EMBO Molecular Medicine 5 1335-1350. (https://doi.org/10.1002/emmm.201302625)

Gattelli A, Garcia Sola ME, Roloff TC, Cardiff RD, Kordon EC, Chodosh LA \& Hynes NE 2018 Chronic expression of wild-type Ret receptor in the mammary gland induces luminal tumors that are sensitive to Ret inhibition. Oncogene. (https://doi.org/10.1038/ s41388-018-0235-y)

Gautschi O, Milia J, Filleron T, Wolf J, Carbone DP, Owen D, Camidge R, Narayanan V, Doebele RC, Besse B, et al. 2017 Targeting RET in patients with RET-rearranged lung cancers: results from the global, multicenter RET registry. Journal of Clinical Oncology 35 1403-1410. (https://doi.org/10.1200/JCO.2016.70.9352)

Gil Z, Cavel O, Kelly K, Brader P, Rein A, Gao SP, Carlson DL, Shah JP, Fong Y \& Wong RJ 2010 Paracrine regulation of pancreatic cancer cell invasion by peripheral nerves. Journal of the National Cancer Institute 102 107-118. (https://doi.org/10.1093/jnci/djp456)

Gild ML, Landa I, Ryder M, Ghossein RA, Knauf JA \& Fagin JA 2013 Targeting mTOR in RET mutant medullary and differentiated thyroid cancer cells. Endocrine-Related Cancer 20 659-667. (https://doi. org/10.1530/ERC-13-0085)

Grey J \& Winter K 2018 Patient quality of life and prognosis in multiple endocrine neoplasia type 2. Endocrine-Related Cancer 25 T69-T77. (https://doi.org/10.1530/ERC-17-0335)

Gujral TS, Singh VK, Jia Z \& Mulligan LM 2006 Molecular Mechanisms of RET Receptor-Mediated Oncogenesis in Multiple Endocrine Neoplasia 2B. Cancer Research 66 10741-10749. (https://doi. org/10.1158/0008-5472.CAN-06-3329)

Hamatani K, Eguchi H, Ito R, Mukai M, Takahashi K, Taga M, Imai K, Cologne J, Soda M, Arihiro K, et al. 2008 RET/PTC rearrangements preferentially occurred in papillary thyroid cancer among atomic bomb survivors exposed to high radiation dose. Cancer Research $\mathbf{6 8}$ 7176-7182. (https://doi.org/10.1158/0008-5472.CAN-08-0293)

Hatem R, Labiod D, Chateau-Joubert S, de Plater L, El Botty R, Vacher S, Bonin F, Servely JL, Dieras V, Bieche I, et al. 2016 Vandetanib as a potential new treatment for estrogen receptor-negative breast cancers. International Journal of Cancer 138 2510-2521. (https://doi. org/10.1002/ijc.29974)

Hyndman BD, Crupi MJF, Peng S, Bone LN, Rekab AN, Lian EY, Wagner SM, Antonescu CN \& Mulligan LM 2017 Differential recruitment of E3 ubiquitin ligase complexes regulates RET isoform internalization. Journal of Cell Science 130 3282-3296. (https://doi. org/10.1242/jcs.203885)

Ibanez CF 2013 Structure and physiology of the RET receptor tyrosine kinase. Cold Spring Harbor Perspectives in Biology 5 a009134. (https:// doi.org/10.1101/cshperspect.a009134)

Ibanez CF \& Andressoo JO 2017 Biology of GDNF and its receptors relevance for disorders of the central nervous system. Neurobiology of Disease 97 80-89. (https://doi.org/10.1016/j.nbd.2016.01.021)

Imai T, Uchino S, Okamoto T, Suzuki S, Kosugi S, Kikumori T, Sakurai A \& Japan MENCo 2013 High penetrance of pheochromocytoma in multiple endocrine neoplasia 2 caused by germ line RET codon 634 mutation in Japanese patients. European Journal of Endocrinology 168 683-687. (https://doi.org/10.1530/EJE-12-1106)

Jasim S, Ying AK, Waguespack SG, Rich TA, Grubbs EG, Jimenez C, $\mathrm{Hu}$ MI, Cote G \& Habra MA 2011 Multiple endocrine neoplasia type 2B with a RET proto-oncogene A883F mutation displays a more indolent form of medullary thyroid carcinoma compared with a RET M918T mutation. Thyroid 21 189-192. (https://doi.org/10.1089/ thy.2010.0328)

Karras S, Pontikides N \& Krassas GE 2013 Pharmacokinetic evaluation of cabozantinib for the treatment of thyroid cancer. Expert Opinion on Drug Metabolism and Toxicology 9 507-515. (https://doi.org/10.1517/1 7425255.2013.780028) 
Kato S, Subbiah V, Marchlik E, Elkin SK, Carter JL \& Kurzrock R 2017 RET aberrations in diverse cancers: next-generation sequencing of 4,871 patients. Clinical Cancer Research 23 1988-1997. (https://doi. org/10.1158/1078-0432.CCR-16-1679)

Knowles PP, Murray-Rust J, Kjaer S, Scott RP, Hanrahan S, Santoro M, Ibanez CF \& McDonald NQ 2006 Structure and chemical inhibition of the RET tyrosine kinase domain. Journal of Biological Chemistry 281 33577-33587. (https://doi.org/10.1074/jbc.M605604200)

Kohno T, Ichikawa H, Totoki Y, Yasuda K, Hiramoto M, Nammo T, Sakamoto H, Tsuta K, Furuta K, Shimada Y, et al. 2012 KIF5B-RET fusions in lung adenocarcinoma. Nature Medicine 18 375-377. (https://doi.org/10.1038/nm.2644)

Kosari F, Ida CM, Aubry MC, Yang L, Kovtun IV, Klein JL, Li Y, Erdogan S, Tomaszek SC, Murphy SJ, et al. 2014 ASCL1 and RET expression defines a clinically relevant subgroup of lung adenocarcinoma characterized by neuroendocrine differentiation. Oncogene 33 3776-3783. (https://doi.org/10.1038/onc.2013.359)

Kumarasamy VM \& Sun D 2017 Demonstration of a potent RET transcriptional inhibitor for the treatment of medullary thyroid carcinoma based on an ellipticine derivative. International Journal of Oncology 51 145-157. (https://doi.org/10.3892/ijo.2017.3994)

Lantieri F, Caroli F, Ceccherini I \& Griseri P 2013 The involvement of the RET variant G691S in medullary thyroid carcinoma enlightened by a meta-analysis study. International Journal of Cancer 132 2808-2819. (https://doi.org/10.1002/ijc.27967)

Lasrado R, Boesmans W, Kleinjung J, Pin C, Bell D, Bhaw L, McCallum S, Zong H, Luo L, Clevers H, et al. 2017 Lineagedependent spatial and functional organization of the mammalian enteric nervous system. Science 356 722-726. (https://doi. org/10.1126/science.aam7511)

Learoyd DL, Marsh DJ, Richardson AL, Twigg SM, Delbridge L \& Robinson BG 1997 Genetic testing for familial cancer. Consequences of RET proto-oncogene mutation analysis in multiple endocrine neoplasia, type 2. Archives of Surgery 132 1022-1025. (https://doi. org/10.1001/archsurg.1997.01430330088015)

Lebeault M, Pinson S, Guillaud-Bataille M, Gimenez-Roqueplo AP, Carrie A, Barbu V, Pigny P, Bezieau S, Rey JM, Delvincourt C, et al. 2017 Nationwide French study of RET variants detected from 2003 to 2013. Suggests a possible influence of polymorphisms as modifiers. Thyroid 27 1511-1522. (https://doi.org/10.1089/ thy.2016.0399)

Leeman-Neill RJ, Brenner AV, Little MP, Bogdanova TI, Hatch M, Zurnadzy LY, Mabuchi K, Tronko MD \& Nikiforov YE 2013 RET/PTC and PAX8/PPARgamma chromosomal rearrangements in postChernobyl thyroid cancer and their association with iodine-131 radiation dose and other characteristics. Cancer 119 1792-1799. (https://doi.org/10.1002/cncr.27893)

Lian EY, Maritan SM, Cockburn JG, Kasaian K, Crupi MJ, Hurlbut D, Jones SJ, Wiseman SM \& Mulligan LM 2017 Differential roles of RET isoforms in medullary and papillary thyroid carcinomas. EndocrineRelated Cancer 24 53-69. (https://doi.org/10.1530/ERC-16-0393)

Liang J, Cai W, Feng D, Teng H, Mao F, Jiang Y, Hu S, Li X, Zhang Y, Liu B, et al. 2018 Genetic landscape of papillary thyroid carcinoma in the Chinese population. Journal of Pathology 244 215-226. (https://doi.org/10.1002/path.5005)

Lin C, Lu W, Ren Z, Tang Y, Zhang C, Yang R, Chen Y, Cao W, Wang L, Wang X, et al. 2016 Elevated RET expression enhances EGFR activation and mediates EGFR inhibitor resistance in head and neck squamous cell carcinoma. Cancer Letters 377 1-10. (https://doi. org/10.1016/j.canlet.2016.04.023)

Lodish MB \& Stratakis CA 2008 RET oncogene in MEN2, MEN2B, MTC and other forms of thyroid cancer. Expert Review of Anticancer Therapy 8 625-632. (https://doi.org/10.1586/14737140.8.4.625)

Luo Y, Tsuchiya KD, Il Park D, Fausel R, Kanngurn S, Welcsh P, Dzieciatkowski S, Wang J \& Grady WM 2013 RET is a potential tumor suppressor gene in colorectal cancer. Oncogene 32 2037-2047. (https://doi.org/10.1038/onc.2012.225)

Machens A \& Dralle H 2008 Familial prevalence and age of RET germline mutations: implications for screening. Clinical Endocrinology 69 81-87. (https://doi.org/10.1111/j.1365-2265.2007.03153.x)

Machens A \& Dralle H 2018 Advances in risk-oriented surgery for multiple endocrine neoplasia type 2. Endocrine-Related Cancer $\mathbf{2 5}$ T41-T52. (https://doi.org/10.1530/ERC-17-0202)

Machens A, Elwerr M, Lorenz K, Weber F \& Dralle H 2018 Long-term outcome of prophylactic thyroidectomy in children carrying RET germline mutations. British Journal of Surgery 105 e150-e157. (https://doi.org/10.1002/bjs.10746)

Margraf RL, Crockett DK, Krautscheid PM, Seamons R, Calderon FR, Wittwer CT \& Mao R 2009 Multiple endocrine neoplasia type 2 RET protooncogene database: repository of MEN2-associated RET sequence variation and reference for genotype/phenotype correlations. Human Mutation 30 548-556. (https://doi.org/10.1002/ humu.20928)

Marsh DJ, McDowall D, Hyland VJ, Andrew SD, Schnitzler M, Gaskin EL, Nevell DF, Diamond T, Delbridge L, Clifton-Bligh P, et al. 1996 The identification of false positive responses to the pentagastrin stimulation test in RET mutation negative members of MEN2A families. Clinical Endocrinology 44 213-220. (https://doi. org/10.1046/j.1365-2265.1996.505292.x)

Mathiesen JS, Habra MA, Bassett JHD, Choudhury SM, Balasubramanian SP, Howlett TA, Robinson BG, GimenezRoqueplo AP, Castinetti F, Vestergaard P, et al. 2017 Risk profile of the RET A883F germline mutation: an international collaborative study. Journal of Clinical Endocrinology and Metabolism 102 2069-2074. (https://doi.org/10.1210/jc.2016-3640)

McWhinney SR, Boru G, Binkley PK, Peczkowska M, Januszewicz AA, Neumann HP \& Eng C 2003 Intronic single nucleotide polymorphisms in the RET protooncogene are associated with a subset of apparently sporadic pheochromocytoma and may modulate age of onset. Journal of Clinical Endocrinology and Metabolism 88 4911-4916. (https://doi.org/10.1210/jc.2003-030245)

Meng X, Lindahl M, Hyvonen ME, Parvinen M, de Rooij DG, Hess MW Raatikainen-Ahokas A, Sainio K, Rauvala H, Lakso M, et al. 2000 Regulation of cell fate decision of undifferentiated spermatogonia by GDNF. Science 287 1489-1493. (https://doi.org/10.1126/ science.287.5457.1489)

Morandi A, Plaza-Menacho I \& Isacke CM 2011 RET in breast cancer: functional and therapeutic implications. Trends in Molecular Medicine 17 149-157. (https://doi.org/10.1016/j.molmed.2010.12.007)

Morandi A, Martin LA, Gao Q, Pancholi S, Mackay A, Robertson D, Zvelebil M, Dowsett M, Plaza-Menacho I \& Isacke CM 2013 GDNFRET signaling in ER-positive breast cancers is a key determinant of response and resistance to aromatase inhibitors. Cancer Research $\mathbf{7 3}$ 3783-3795. (https://doi.org/10.1158/0008-5472.CAN-12-4265)

Moura MM, Cavaco BM, Pinto AE, Domingues R, Santos JR, Cid MO, Bugalho MJ \& Leite V 2009 Correlation of RET somatic mutations with clinicopathological features in sporadic medullary thyroid carcinomas. British Journal of Cancer 100 1777-1783. (https://doi. org/10.1038/sj.bjc.6605056)

Mulligan LM 2014 RET revisited: expanding the oncogenic portfolio. Nature Reviews Cancer 14 173-186. (https://doi.org/10.1038/nrc3680)

Mulligan LM, Kwok JBJ, Healey CS, Elsdon MJ, Eng C, Gardner E, Love DR, Mole SE, Moore JK, Papi L, et al. 1993 Germ-line mutations of the RET proto-oncogene in multiple endocrine neoplasia type $2 \mathrm{~A}$. Nature 363 458-460. (https://doi.org/10.1038/363458a0)

Mulligan LM, Eng C, Healey CS, Clayton D, Kwok JBJ, Gardner E, Ponder MA, Frilling A, Jackson CE, Lehnert H, et al. 1994 Specific mutations of the RET proto-oncogene are related to disease phenotype in MEN 2A and FMTC. Nature Genetics 6 70-74. (https:// doi.org/10.1038/ng0194-70)
(C) 2018 Society for Endocrinology Published by Bioscientifica Ltd. Printed in Great Britain 
Nakao KT, Usui T, Ikeda M, Mori Y, Yamamoto T, Kawashima ST, Nanba K, Yuno A, Tamanaha T, Tagami T, et al. 2013 Novel tandem germline RET proto-oncogene mutations in a patient with multiple endocrine neoplasia type $2 \mathrm{~B}$ : report of a case and a literature review of tandem RET mutations with in silico analysis. Head Neck $\mathbf{3 5}$ E363-E368. (https://doi.org/10.1002/hed.23241)

Narita N, Tanemura A, Murali R, Scolyer RA, Huang S, Arigami T, Yanagita S, Chong KK, Thompson JF, Morton DL, et al. 2009 Functional RET G691S polymorphism in cutaneous malignant melanoma. Oncogene 28 3058-3068. (https://doi.org/10.1038/ onc.2009.164)

Newton R, Bowler KA, Burns EM, Chapman PJ, Fairweather EE, Fritzl SJ, Goldberg KM, Hamilton NM, Holt SV, Hopkins GV, et al. 2016 The discovery of 2-substituted phenol quinazolines as potent RET kinase inhibitors with improved KDR selectivity. European Journal of Medicinal Chemistry 112 20-32. (https://doi.org/10.1016/j. ejmech.2016.01.039)

Nguyen M, Miyakawa S, Kato J, Mori T, Arai T, Armanini M, Gelmon K, Yerushalmi R, Leung S, Gao D, et al. 2015 Preclinical efficacy and safety assessment of an antibody-drug conjugate targeting the c-RET proto-oncogene for breast carcinoma. Clinical Cancer Research 21 5552-5562. (https://doi.org/10.1158/1078-0432.CCR-15-0468)

Paratcha G \& Ledda F 2008 GDNF and GFRalpha: a versatile molecular complex for developing neurons. Trends in Neurosciences 31 384-391. (https://doi.org/10.1016/j.tins.2008.05.003)

Plaza-Menacho I 2018 Structure and function of RET in multiple endocrine neoplasia type 2. Endocrine-Related Cancer 25 T79-T90. (https://doi.org/10.1530/ERC-17-0354)

Plaza-Menacho I, Morandi A, Robertson D, Pancholi S, Drury S, Dowsett M, Martin LA \& Isacke CM 2010 Targeting the receptor tyrosine kinase RET sensitizes breast cancer cells to tamoxifen treatment and reveals a role for RET in endocrine resistance. Oncogene 29 4648-4657. (https://doi.org/10.1038/onc.2010.209)

Reckamp KL, Rich TA, Chae Y, Doebele RC, Iams WT, Oh M, Raymond VM, Lanman RB, Stinchcombe TE, Subbiah V, et al. 2018 Analysis of cell-free DNA from 32,991 advanced cancers reveals novel co-occurring activating RET alterations and oncogenic signaling pathway aberrations. In Proceedings of the 109th Annual Meeting of the American Association for Cancer Research, 2018, abstract 936. Chicago, Illinois: AACR.

Redaelli S, Plaza-Manacho I \& LMologni L 2018 Novel targeted therapeutics for MEN 2. Endocrine-Related Cancer 25 T53-T68. (https://doi.org/10.1530/ERC-17-0297)

Richardson DS, Gujral TS, Peng S, Asa SL \& Mulligan LM 2009 Transcript level modulates the inherent oncogenicity of RET/PTC oncoproteins. Cancer Research 69 4861-4869. (https://doi. org/10.1158/0008-5472.CAN-08-4425)

Robledo M, Gil L, Pollan M, Cebrian A, Ruiz S, Azanedo M, Benitez J, Menarguez J \& Rojas JM 2003 Polymorphisms G691S/S904S of RET as genetic modifiers of MEN 2A. Cancer Research 63 1814-1817.

Romei C, Cosci B, Renzini G, Bottici V, Molinaro E, Agate L, Passannanti P, Viola D, Biagini A, Basolo F, et al. 2011 RET genetic screening of sporadic medullary thyroid cancer (MTC) allows the preclinical diagnosis of unsuspected gene carriers and the identification of a relevant percentage of hidden familial MTC (FMTC). Clinical Endocrinology 74 241-247. (https://doi. org/10.1111/j.1365-2265.2010.03900.x)

Romei C, Ciampi R \& Elisei R 2016 A comprehensive overview of the role of the RET proto-oncogene in thyroid carcinoma. Nature Reviews Endocrinology 12 192-202. (https://doi.org/10.1038/ nrendo.2016.11)

Sanso GE, Domene HM, Garcia R, Pusiol E, de M, Roque M, Ring A, Perinetti H, Elsner B, Iorcansky S, et al. 2002 Very early detection of RET proto-oncogene mutation is crucial for preventive thyroidectomy in multiple endocrine neoplasia type 2 children: presence of C-cell malignant disease in asymptomatic carriers. Cancer 94 323-330. (https://doi.org/10.1002/cncr.10228)

Sawai H, Okada Y, Kazanjian K, Kim J, Hasan S, Hines OJ, Reber HA, Hoon DS \& Eibl G 2005 The G691S RET polymorphism increases glial cell line-derived neurotrophic factor-induced pancreatic cancer cell invasion by amplifying mitogen-activated protein kinase signaling. Cancer Research 65 11536-11544. (https://doi. org/10.1158/0008-5472.CAN-05-2843)

Schlumberger M, Elisei R, Müller S, Schöffski P, Brose MS, Shah MH, Licitra LF, Jarzab B, Medvedev V, Kreissl M, et al. 2015 Final overall survival analysis of EXAM, an international, double-blind, randomized, placebo-controlled phase III trial of cabozantinib (Cabo) in medullary thyroid carcinoma (MTC) patients with documented RECIST progression at baseline. Journal of Clinical Oncology 33 S6012.

Schlumberger M, Elisei R, Muller S, Schoffski P, Brose M, Shah M, Licitra L, Krajewska J, Kreissl MC, Niederle B, et al. 2017 Overall survival analysis of EXAM, a phase III trial of cabozantinib in patients with radiographically progressive medullary thyroid carcinoma. Annals of Oncology 28 2813-2819. (https://doi. org/10.1093/annonc/mdx479)

Schuchardt A, D'Agati V, Larsson-Blomberg L, Costantini F \& Pachnis V 1994 Defects in the kidney and enteric nervous system of mice lacking the tyrosine kinase receptor RET. Nature 367 380-383. (https://doi.org/10.1038/367380a0)

Siqueira DR, Ceolin L, Ferreira CV, Romitti M, Maia SC, Maciel LM \& Maia AL 2014 Role of RET genetic variants in MEN2-associated pheochromocytoma. European Journal of Endocrinology 170 821-828. (https://doi.org/10.1530/EJE-14-0084)

Stransky N, Cerami E, Schalm S, Kim JL \& Lengauer C 2014 The landscape of kinase fusions in cancer. Nature Communications 54846. (https://doi.org/10.1038/ncomms5846)

Subbiah V, Berry J, Roxas M, Guha-Thakurta N, Subbiah IM, Ali SM, McMahon C, Miller V, Cascone T, Pai S, et al. 2015 Systemic and CNS activity of the RET inhibitor vandetanib combined with the mTOR inhibitor everolimus in KIF5B-RET re-arranged non-small cell lung cancer with brain metastases. Lung Cancer 89 76-79. (https:// doi.org/10.1016/j.lungcan.2015.04.004)

Subbiah V, Gainor JF, Rahal R, Brubaker JD, Kim JL, Maynard M, Hu W, Cao Q, Sheets MP, Wilson D, et al. 2018a Precision targeted therapy with BLU-667 for RET-driven cancers. Cancer Discovery. (https://doi. org/10.1158/2159-8290.CD-18-0338)

Subbiah V, Velcheti V, Tuch BB, Ebata K, Busaidy NL, Cabanillas ME, Wirth LJ, Stock S, Smith S, Lauriault V, et al. $2018 b$ Selective RET kinase inhibition for patients with RET-altered cancers. Annals of Oncology [epub]. (https://doi.org/10.1093/annonc/mdy137)

Toledo RA, Wagner SM, Coutinho FL, Lourenco DM Jr, Azevedo JA, Longuini VC, Reis MT, Siqueira SA, Lucon AM, Tavares MR, et al. 2010 High penetrance of pheochromocytoma associated with the novel C634Y/Y791F double germline mutation in the RET protooncogene. Journal of Clinical Endocrinology and Metabolism 95 1318-1327. (https://doi.org/10.1210/jc.2009-1355)

Toledo RA, Hatakana R, Lourenco DM Jr, Lindsey SC, Camacho CP, Almeida M, Lima JV Jr, Sekiya T, Garralda E, Naslavsky MS, et al. 2015 Comprehensive assessment of the disputed RET Y791F variant shows no association with medullary thyroid carcinoma susceptibility. Endocrine-Related Cancer 22 65-76. (https://doi. org/10.1530/ERC-14-0491)

Tsui CC, Gabreski NA, Hein SJ \& Pierchala BA 2015 Lipid rafts are physiologic membrane microdomains necessary for the morphogenic and developmental functions of glial cell line-derived neurotrophic factor in vivo. Journal of Neuroscience 35 13233-13243. (https://doi. org/10.1523/JNEUROSCI.2935-14.2015)

Viola D, Valerio L, Molinaro E, Agate L, Bottici V, Biagini A, Lorusso L, Cappagli V, Pieruzzi L, Giani C, et al. 2016 Treatment of advanced thyroid cancer with targeted therapies: ten years of experience. (c) 2018 Society for Endocrinology Published by Bioscientifica Ltd. Printed in Great Britain 
Endocrine-Related Cancer 23 R185-R205. (https://doi.org/10.1530/ ERC-15-0555)

Voss RK, Feng L, Lee JE, Perrier ND, Graham PH, Hyde SM, NievesMunoz F, Cabanillas ME, Waguespack SG, Cote GJ, et al. 2017 Medullary thyroid carcinoma in MEN2A: ATA moderate- or high-risk RET mutations do not predict disease aggressiveness. Journal of Clinical Endocrinology and Metabolism 102 2807-2813. (https://doi. org/10.1210/jc.2017-00317)

Wang X 2013 Structural studies of GDNF family ligands with their receptors-Insights into ligand recognition and activation of receptor tyrosine kinase RET. Biochimica et Biophysica Acta 1834 2205-2212. (https://doi.org/10.1016/j.bbapap.2012.10.008)

Wang C, Mayer JA, Mazumdar A \& Brown PH 2012 The rearranged during transfection/papillary thyroid carcinoma tyrosine kinase is an estrogen-dependent gene required for the growth of estrogen receptor positive breast cancer cells. Breast Cancer Research and Treatment 133 487-500. (https://doi.org/10.1007/s10549-011$1775-9)$

Wells SA Jr 2018 Advances in the management of MEN 2. EndocrineRelated Cancer 25 T1-T13. (https://doi.org/10.1530/ERC-17-0325)

Wells S, Chi D, Toshima K, Dehner L, Coffin C, Dowton B, Ivanovich J, DeBenedetti M, Dilley W, Moley J, et al. 1994 Predictive DNA testing and prophylactic thyroidectomy in patients at risk for multiple endocrine neoplasia type 2A. Annals of Surgery 220 237-250. (https:// doi.org/10.1097/00000658-199409000-00002)

Wells SA Jr, Robinson BG, Gagel RF, Dralle H, Fagin JA, Santoro M, Baudin E, Elisei R, Jarzab B, Vasselli JR, et al. 2012 Vandetanib in patients with locally advanced or metastatic medullary thyroid cancer: a randomized, double-blind phase III trial. Journal of Clinical Oncology 30 134-141. (https://doi.org/10.1200/JCO.2011.35.5040)
Wells SA Jr, Asa SL, Dralle H, Elisei R, Evans DB, Gagel RF, Lee N, Machens A, Moley JF, Pacini F, et al. 2015 Revised American Thyroid Association guidelines for the management of medullary thyroid carcinoma. Thyroid 25 567-610. (https://doi.org/10.1089/ thy.2014.0335)

Wiesner T, He J, Yelensky R, Esteve-Puig R, Botton T, Yeh I, Lipson D, Otto G, Brennan K, Murali R, et al. 2014 Kinase fusions are frequent in Spitz tumours and spitzoid melanomas. Nature Communications $\mathbf{5}$ 3116. (https://doi.org/10.1038/ncomms4116)

Xing M 2013 Molecular pathogenesis and mechanisms of thyroid cancer. Nature Reviews Cancer 13 184-199. (https://doi.org/10.1038/ $\operatorname{nrc3431)}$

Yoh K, Seto T, Satouchi M, Nishio M, Yamamoto N, Murakami H, Nogami N, Matsumoto S, Kohno T, Tsuta K, et al. 2017 Vandetanib in patients with previously treated RET-rearranged advanced nonsmall-cell lung cancer (LURET): an open-label, multicentre phase 2 trial. Lancet Respiratory Medicine 5 42-50. (https://doi.org/10.1016/ S2213-2600(16)30322-8)

Zenaty D, Aigrain Y, Peuchmaur M, Philippe-Chomette P, Baumann C, Cornelis F, Hugot JP, Chevenne D, Barbu V, Guillausseau PJ, et al. 2009 Medullary thyroid carcinoma identified within the first year of life in children with hereditary multiple endocrine neoplasia type $2 \mathrm{~A}$ (codon 634) and 2B. European Journal of Endocrinology 160 807-813. (https://doi.org/10.1530/EJE-08-0854)

Zeng Q, Cheng Y, Zhu Q, Yu Z, Wu X, Huang K, Zhou M, Han S \& Zhang Q 2008 The relationship between overexpression of glial cellderived neurotrophic factor and its RET receptor with progression and prognosis of human pancreatic cancer. Journal of International Medical Research 36 656-664. (https://doi. org/10.1177/147323000803600406)

Received in final form 4 May 2018

Accepted 8 May 2018

Accepted Preprint published online 9 May 2018 http://erc.endocrinology-journals.org https://doi.org/10.1530/ERC-18-0141 (c) 2018 Society for Endocrinology Published by Bioscientifica Ltd. Printed in Great Britain 